\title{
Ocena wiedzy i zachowań społecznych powiatu bełchatowskiego na temat HIV i AIDS
}

\section{Assessment of knowledge and social behaviour of Belchatow district on HIV and AIDS}

IWONA DYLAK¹, BOGUSŁAWA SERZYSKO2,3

\author{
${ }^{1}$ Studentka WSPS Dąbrowa Górnicza \\ 2 Śląskie Centrum Chorób Serca w Zabrzu, Katedra Kardiologii Wad Wrodzonych Serca \\ i Elektroterapii z Oddziałem Kardiologii Dziecięcej Śląskiego Uniwersytetu Medycznego \\ w Katowicach \\ 3 WSPS Dąbrowa Górnicza
}

DOI: http://dx.doi.org/10.21784/IwP.2018.008

ISSN: $2451-1846$

\section{Streszczenie:}

Wstęp. W dzisiejszych czasach problem HIV/AIDS jest bardzo istotny. Mimo, że mamy w Polsce bardzo dobry dostęp do leczenia HIV/AIDS, bez żadnych finansowych ograniczeń, nadal problemem jest wzrost zakażeń wirusem HIV. Społeczeństwo, a zwłaszcza ludzie młodzi nie mają podstawowej wiedzy na temat HIV/AIDS i nie odnoszą do siebie możliwości zakażenia. Wpływa na to wzrost ryzykownych zachowań seksualnych, zażywanie substancji psychoaktywnych, a także zbyt niskie poczucie zagrożenia zakażenia HIV. Medycyna nadal nie zna leku, który całkowicie eliminuje wirusa z organizmu. Statystyki są niepokojące, pokazują, że każdego dnia w Polsce dwie osoby dowiadują się o swoim zakażeniu. Wśród społeczeństwa wyraźnie widać niechęć do wykonywania testów na obecność wirusa HIV.

Cel. Celem pracy była ocena poziomu wiedzy społeczeństwa powiatu bełchatowskiego w przedziale wiekowym 19 - 49 lat na temat HIV/AIDS. 
Materiał i metody. Badania przeprowadzono w styczniu 2017 roku przy użyciu kwestionariusza ankiety, wśród losowo wybranych mieszkańców miasta Bełchatowa i jego okolic.

Wyniki. Wiedza badanych na temat HIV i AIDS była na poziomie umiarkowanym. Badani średnio udzielali 53,07\% prawidłowych odpowiedzi na pytania dotyczące różnych kwestii związanych z HIV i AIDS.

Źródłami informacji, z jakich badani poznawali temat HIV i AIDS, najczęściej były: Internet, telewizja oraz prasa i czasopisma. W przypadku Internetu oraz prasy i czasopism nie zanotowano istotnego wpływu na poziom wiedzy badanych na temat HIV i AIDS. Natomiast telewizja istotnie obniżała poziom tej wiedzy i tym samym nie była dobrym źródłem informacji na ten temat. Taki sam wpływ na poziom wiedzy w zakresie HIV i AIDS mieli znajomi, którzy również istotnie obniżali poziom wiedzy na ten temat. Z kolei, wszystkie pozostałe źródła informacji (tj. literatura, kampanie społeczne, uczelnie i szkoły oraz ulotki) istotnie poprawiały poziom wiedzy w tym zakresie, a tym samym stanowiły dobre źródło informacji na ten temat.

Wnioski. Ponieważ obserwuje się niebezpieczne lekceważenie wirusa HIV, należy duży nacisk położyć na edukację, podnoszenie świadomości społecznej tak, aby ludzie potrafili oceniać ryzykowne sytuacje oraz znali metody, które skutecznie będą zapobiegać zakażeniu. Przemyślane decyzje i zdrowy rozsądek chronią od ryzyka zakażenia HIV, a to przyczynia się do zmniejszenia ludzkich dramatów wywołanych zachorowaniem na AIDS.

Słowa kluczowe: AIDS, HIV, poziom wiedzy

\begin{abstract}
:
Introduction. Nowadays the problem of HIV / AIDS is crucial. Although we have very good access to HIV /AIDS treatment in Poland, without any financial limitations, the HIV infection is still growing. Society and especially young people, do not have basic knowledge about HIV / AIDS and close their minds to the possibility of infection. This has a great influence on the increase of risky sexual behavior, the use of psychoactive substances, as well as ingoring risk of HIV infection. Medicine still does not know the drug that completely eliminates the virus from the body. Statistics are disturbing and show that two people in Poland find out about their infection daily. People are clearly reluctant to perform HIV tests.
\end{abstract}


Aim. The aim of the study was to assess the level of knowledge of HIV / AIDS among people of 19-49 years of age in Belchatow.

Material and methods. The research was carried out in January 2017 using a questionnaire survey, among randomly selected residents of the city of Bełchatów and its surroundings.

Results. The knowledge of respodents of HIV and AIDS was moderate. They gave an average of $53.07 \%$ of correct answers to questions about various HIV and AIDS issues. The source of information about HIV and AIDS for the respondents was most often: the Internet, television, the press and magazines. In case of the Internet, the press and magazines there was no significant impact on the level of knowledge of the respondents on HIV and AIDS. On the other hand, television significantly reduced the level of this knowledge and thus was not a good source of information on this subject. The same influence on the level of knowledge in the field of HIV and AIDS had respondents' friends who also significantly reduced the level of knowledge on the subject. However, all other sources of information (e.i.literature, social campaigns, colleges and schools, and leaflets) significantly improved the level of knowledge in this area, and thus they were a good source of information on this subject.

Conclusions. Because it is dangerous to neglect the HIV virus, emphasis should be placed on education, raising public awareness so that people can assess risky situations and know methods that will effectively prevent infection. Well-considered decisions and common sense protect against the risk of HIV infection, and this contributes to reducing the human dramas caused by developing AIDS.

Keywords: AIDS, HIV, level of knowledge

\section{Wstęp}

W 2016 roku minęło 35 lat od pierwszego zdiagnozowanego przypadku zachorowania na AIDS. Mimo zaawansowanych badań, postępu medycyny, nowych metod diagnostyki oraz leczenia, świat nadal stoi przed problemem, jakim jest rozprzestrzenianie się wirusa HIV. Pandemia HIV/AIDS ciągle dziesiątkuje ludzkość, nie udało się do tej pory opracować bezpiecznej i skutecznej szczepionki przeciw 
wirusowi HIV. Liczba nosicieli HIV i chorych na AIDS ciągle rośnie. Z powodu AIDS na świecie zmarło już ponad 30 milionów osób, a każdego dnia około 1 milion osób zakaża się wirusem HIV na drodze kontaktów seksualnych.

W Polsce pierwsze przypadki zakażeń wirusem HIV zarejestrowano w 1985 roku. Według danych PZH, dotychczas liczba zakażeń przekroczyła 18500 tys. Trzeba jednak pamiętać, że prawdziwa liczba jest najprawdopodobniej około trzykrotnie większa. Do 2014 roku rozpoznano 3200 przypadków zachorowania na AIDS, zmarło ponad 1200 osób. Najnowsze dostępne badania wykazują, że w Polsce liczba osób zakażonych rośnie z roku na rok. Rocznie w Polsce wykrywa się ponad 800 nowych zakażeń HIV.

Początki epidemii połączone były ze strachem o sposób przenoszenia wirusa HIV. Pierwsze doniesienia mówiły o prostytutkach, homoseksualistach i narkomanach, którzy przenoszą zakażenie. W mentalności polskiego społeczeństwa utkwiły one, jako tzw. grupy ryzyka. Osoba zakażona HIV była kojarzona z osobą niemoralną z marginesu społecznego. Poziom wiedzy na temat tego ważnego problemu, jakim jest HIV/AIDS w naszym społeczeństwie niestety nie jest wysoki. Nadal krążą stereotypy, brakuje nam podstawowej wiedzy, co prowadzi do zwiększenia fobii oraz negatywnych zachowań w stosunku do osób zakażonych HIV.

Polacy odnoszą się z rezerwą do badań profilaktycznych. Krajowe Centrum do spraw AIDS, co roku przeprowadza kampanie oraz akcje informujące o zagrożeniach i przeciwdziałaniu zakażeniu HIV. Co 2 lata odbywają się światowe konferencje na temat HIV i AIDS poświęcone problematyce profilaktyki oraz sytuacji optymalne rozwiązania dla obecnej „epidemii” HIV, a największe kraje świata przekraczają corocznie milionowe kwoty na walkę z chorobą naszej cywilizacji. Nie rozwiąże to jednak całkowicie sprawy, jeśli społeczeństwa nie będą w odpowiedni sposób uświadamiane oraz edukowane. Dlatego tak ważne jest zapobieganie zakażeniom wirusem HIV poprzez przekazywanie wiedzy opartej na naukowych faktach 
oraz kształtowanie zachowań prozdrowotnych tak, aby nie tylko wzrastała świadomość i odpowiedzialność za swoje zdrowie i życie, ale również za zdrowie innych.

HIV (Human Immunodeficiency Virus) jest ludzkim wirusem upośledzenia odporności, który powoduje postępującą degradację układu immunologicznego, co w konsekwencji prowadzi do rozwoju AIDS - zespołu nabytego niedoboru odporności.

AIDS (Acquired Immunodeficiency Syndrome) jest zaawansowanym stadium zakażenia wirusem HIV i charakteryzuje się zmniejszeniem liczby limfocytów T CD4 oraz występowaniem zakażeń oportunistycznych i nowotworów [1].

Zakażenia i nowotwory oportunistyczne są chorobami występującymi niemal wyłącznie wśród chorych z głębokim upośledzeniem odporności. Zakażenia wywoływane są przez drobnoustroje, które zwykle są niegroźne dla osób, u których czynność układu immunologicznego jest prawidłowa [2].

Wirus HIV należy do rodziny retrowirusów. Wyróżnia się jego dwa typy: HIV - 1 - jest odpowiedzialny za większość zakażeń u ludzi oraz HIV - 2 rzadziej powoduje zakażenie i chorobę u ludzi [3].

Pierwsze doniesienie na świecie na temat AIDS ukazało się w czerwcu 1981 roku w biuletynie Morbidity and Mortality Weekly Report, które było wydawane przez CDC (Centers of Diseases Control) w Atlancie . Opisywano tam przypadki zachorowań u młodych (29- 36 lat) zdrowych dotąd mężczyzn na zapalenia płuc wywołane przez Pneumocystis carinii. Ponadto u każdego $\mathrm{z}$ nich stwierdzono infekcję wywołaną wirusem cytomegalii oraz kandydozy błon śluzowych. Kilka miesięcy później opublikowano bardziej szczegółowe doniesienia na temat tej nowej choroby, które wzbudziły duże zainteresowanie klinicystów z Europy Zachodniej i USA [3]. W opisywanych przypadkach zachorowań, które występowały wśród homoseksualistów i narkomanów - pacjenci charakteryzowali się infekcjami wywołanymi wirusem cytomegalii, stanami gorączkowymi a także utratą masy ciała. U niektórych $\mathrm{z}$ nich obserwowano 
występowanie owrzodzeń około odbytowych oraz mięsaka Kaposiego [3].

Na podstawie analizy 593 stwierdzonych przypadków zespołu nabytego niedoboru odporności na terenie USA w 1982 roku, powstała pierwsza na świecie definicja AIDS. Opisywano chorobę, jako upośledzenie odporności komórkowej, potwierdzone badaniami, w wyniku której dochodziło do rozwoju zapalenia płuc wywołanego przez Pneumocystis carinii, infekcji oportunistycznych i mięsaka Kaposiego. Ta definicja opierała się przede wszystkim na objawach klinicznych, ponieważ wtedy nie była znana etiologia choroby [3].

W 1983 roku prof. Luc Montagnier z instytutu Pasteura we Francji dokonał wstępnej izolacji wirusa powodującego spadek odporności określonego, jako HIV. W tym samym czasie opracowano pierwsze testy, które pozwalały na identyfikację zakażenia. Z badań jednak wynika, iż w Europie, USA oraz w Afryce przypadki AIDS występowały znacznie wcześniej. Istnieją doniesienia o śmierci marynarza z Norwegii, który zmarł pod koniec lat 50 na podobną jak AIDS chorobę. Najstarsza próbka krwi zakażonej HIV pochodzi z Zairu z 1959 roku . Podobne próbki zostały znalezione w Ugandzie w 1972 roku i w Malawii w 1974 roku [4].

Początkowo AIDS zyskało kryptonim „cztery H”, próbowano w ten sposób przyporządkować, kogo dotyczy ta nowa choroba: hemofilików, homoseksualistów, narkomanów uzależnionych od heroiny czy Haitańczyków. Takie przyporządkowanie zostało na lata wprowadzone do powszechnego myślenia. Trudno było później opinię publiczną przekonać, że zakażenie HIV może dotyczyć nie tylko wybranych grup, ale każdego człowieka [4].

Na AIDS w Polsce pierwsza osoba zmarła w 1985 roku. Był nim polskiego pochodzenia obywatel USA, który wrócił do Polski na kilka tygodni przed śmiercią. W październiku 1986 roku rozporządzeniem Rady Ministrów AIDS zostało wpisane na listę chorób zakaźnych, które podlegają przymusowemu leczeniu ambulatoryjnemu [4]. Pierwsze przypadki zakażenia wirusem HIV 
w Polsce zdiagnozowane zostały w 1985 roku, a pierwszy przypadek zachorowania na AIDS w rok później. W 1987 roku wprowadzono obowiązkowo badania na obecność przeciwciał anty - HIV każdej próbki krwi w stacjach krwiodawstwa. Do końca roku 1987 rozpoznane zostały trzy przypadki AIDS u jednego biseksualisty i dwóch homoseksualistów, u których do zakażenia doszło poza granicami Polski. W 1988 roku rozpoznano zakażenie pierwszego narkomana w Polsce, który stosował dożylne środki odurzające [4].

Od 1985 do końca 2012 roku stwierdzono zakażenie wirusem HIV u 16314 obywateli Polski oraz u osób przebywających na terenie Polski. Odnotowano 2848 zachorowań na AIDS, a zmarło 1185 chorych . Trzeba pamiętać, że w Polsce bardzo mały odsetek osób robi test w kierunku HIV. Z danych wynika, że około 50-70 \% zakażonych Polaków nie posiada wiedzy o swoim statusie serologicznym [4].

Definiując AIDS spotykamy pewne rozbieżności między teorią a kliniczną praktyką. Zgodnie z ostatnią z kolei definicją podaną przez Centrum Zwalczania i Zapobiegania Chorobom w USA, zespół ten określa występowanie jednej z 29 chorób znacznikowych a także wynik dodatniego testu na obecność wirusa HIV [5]. Można przypuszczać, że wyznacznikiem wspólnym dla tych chorób jest związek z zaburzeniami odporności, czego nie można wykazać w kilku przypadkach takich jak: rak szyjki macicy, mięsak Kaposiego, chłoniak czy demencja. Również rozpoznanie AIDS stawiane jest u pacjentów, na podstawie obniżenia poziomu leukocytów T4 poniżej $200 / \mathrm{ml}$ z potwierdzeniem dodatniego testu na obecność wirusa HIV. Chorzy, którzy prezentują pełen zespół objawów AIDS, przy braku dodatniego testu na nosicielstwo znajdują się niejako na drugim biegunie. Choroby znacznikowe AIDS to infekcje spowodowane przez mikroby oportunistyczne (wirusy, bakterie i grzyby), których aktywność patologiczna jest możliwa jedynie $w$ warunkach zaburzeń układu immunologicznego gospodarza. Oczywiste jest, że takie zakażenia nie są przenoszone na zdrowych ludzi, którzy kontaktują się z ludźmi chorymi na AIDS, w tym również na personel medyczny [5]. 
Ludzki wirus upośledzenia odporności jest wrażliwy na czynniki zewnętrzne. Poza organizmem człowieka, w temperaturze pokojowej w warunkach eksperymentalnych może przetrwać do 3 dni, ale już po upływie kilkunastu godzin, 99\% jego populacji jest inaktywowane. Wirus wykazuje także wrażliwość na podstawowe środki odkażające i podwyższoną temperaturę. Para wodna pod ciśnieniem lub tlenek etylenu wystarczają w zupełności do sterylizacji skażonego HIV sprzętu [6]. Zakażona osoba może być źródłem zakażenia do końca życia. Jakkolwiek wirus znajduje się $w$ wielu tkankach, płynach ustrojowych, wydzielinach i wydalinach takich jak: krew, wydzielina pochwy i szyjki macicy, nasienie, kobiece mleko, płyn mózgowo - rdzeniowy, mocz i kał, to jednak rolę nośnika wirusa praktycznie odgrywa krew, nasienie i mleko kobiece. Codzienne, zwykłe kontakty z nosicielem wirusa nie prowadzą do zakażenia. Wirus nie jest przenoszony drogą pokarmową, powietrzną ani przez owady - badania wykazują, że nie namnaża się w organizmach komarów i pluskwiaków [6].

Monitorowanie zakażeń HIV/AIDS w Polsce określa ustawa o obowiązku zgłaszania wszystkich nowo wykrytych zakażeń HIV, przypadków zachorowań na AIDS, jak również zgonów w wyniku AIDS do stacji sanitarno - epidemiologicznych. Te dane są na bieżąco aktualizowane przez PZH. Dzięki temu możemy obserwować, jakie są trendy epidemii HIV w Polsce [7].

Celem pracy była ocena poziomu wiedzy społeczeństwa powiatu bełchatowskiego w przedziale wiekowym 19 - 49 lat na temat HIV/AIDS.

\section{Materiał i metody}

Badania przeprowadzono w 2017 roku, wśród mieszkańców powiatu bełchatowskiego. Badaniem objęto 150 osób, w wieku 19 49 lat. Dobór badanej grupy odbył się w sposób losowy. Przed przystąpieniem do badań respondenci zostali poinformowani, jaki jest cel badań, a także o dobrowolnym w nich udziale. Otrzymali informacje 
odnośnie wypełnienia ankiety oraz zapewnienie o anonimowości uzyskanych danych. Respondenci wypełnili autorską ankietę opracowaną dla potrzeb badania, która zawierała 30 pytań o charakterze zamkniętym. Podstawą oceny wyników była procentowa ilość odpowiedzi uzyskanych na poszczególne pytania.

\section{Wyniki}

W pierwszej kolejności analizie poddano rozkład odpowiedzi respondentów na pytania dotyczące wiedzy na temat HIV i AIDS. Poniższe wykresy przedstawiają analizę ilościową tych wyników.

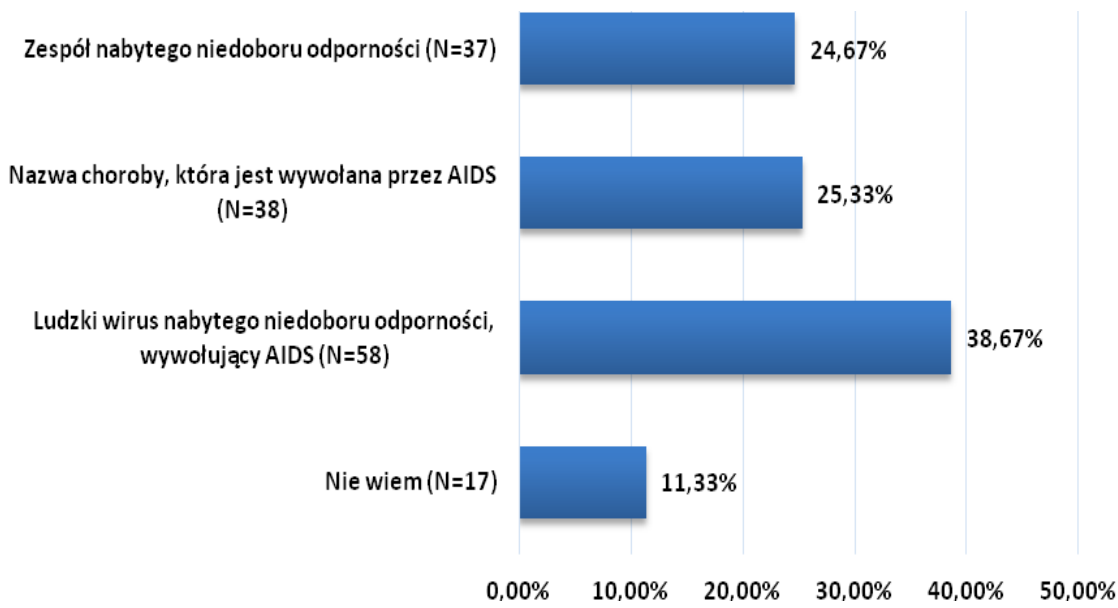

\section{Rycina 1. Wiedza badanych, co oznacza skrót HIV.}

Źródło: wynik badań własnych

Na pytanie, co oznacza skrót HIV ankietowani najczęściej (38,67\%) wskazywali, że HIV oznacza ludzki wirus nabytego niedoboru odporności wywołujący AIDS. Według co czwartego respondenta jest to nazwa choroby, która jest wywoływana przez AIDS $(25,33 \%)$ i niemal tyle samo osób $(24,67 \%)$ uważało, że jest to zespół nabytego niedoboru odporności. Z kolei, co dziewiąta osoba $(11,33 \%)$ przyznawała, że nie ma wiedzy na ten temat. 


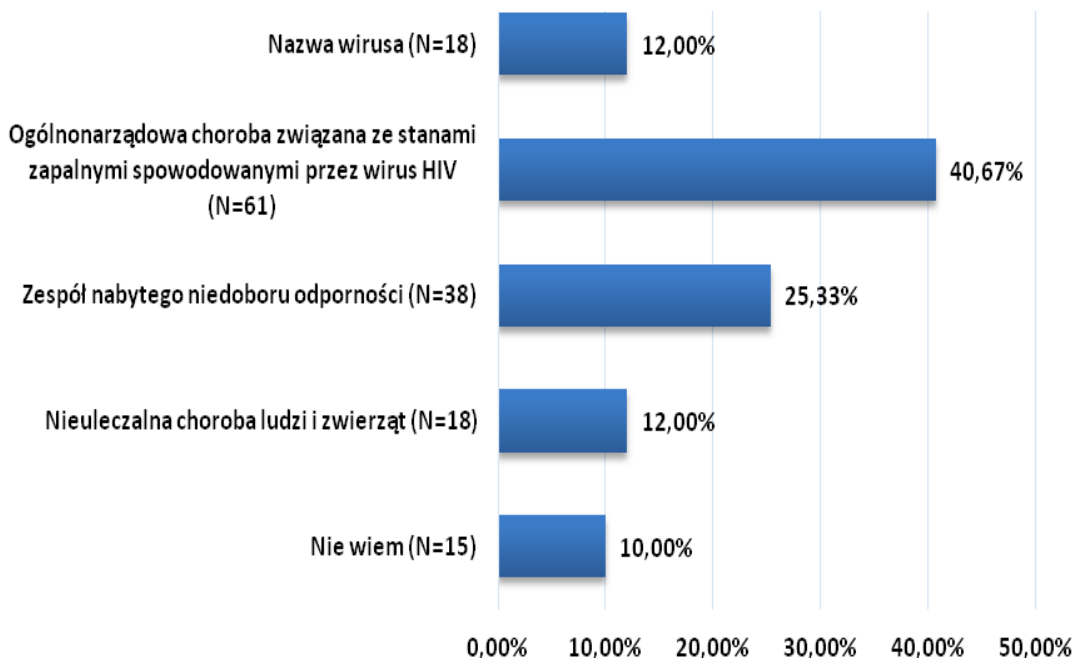

Rycina 2. Wiedza badanych, co oznacza skrót AIDS.

Źródło: wynik badań własnych

Natomiast, na pytanie, co oznacza skrót AIDS, badani najczęściej $(40,67 \%)$ wskazywali, że jest to ogólnonarządowa choroba związana ze stanami zapalnymi spowodowanymi przez wirus HIV. Co czwarty respondent (25,33\%) wskazał, że skrót AIDS oznacza zespół nabytego niedoboru odporności. Odpowiednio po $12,00 \%$ badanych wskazało, że skrót ten oznacza nazwę wirusa i nieuleczalną chorobę ludzi i zwierząt. Z kolei, co dziesiąty ankietowany $(10,00 \%)$ przyznawał, że nie ma wiedzy na ten temat. 


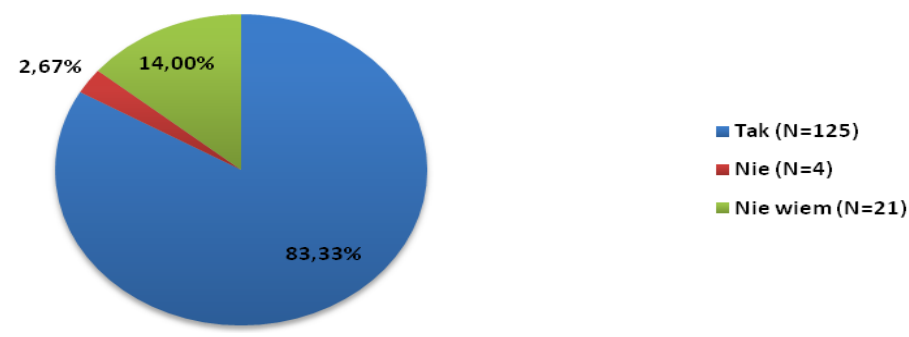

Rycina 3. Wiedza badanych na temat niszczenia przez HIV układu odpornościowego człowieka.

Źródło: wynik badań własnych

Zdecydowana większość badanych $(83,33 \%)$ była zdania, że wirus HIV niszczy układ odpornościowy człowieka. Przeciwnego zdania było tyko $2,67 \%$ badanych. Pozostałe $14,00 \%$ badanych nie posiadało wiedzy w tym zakresie.

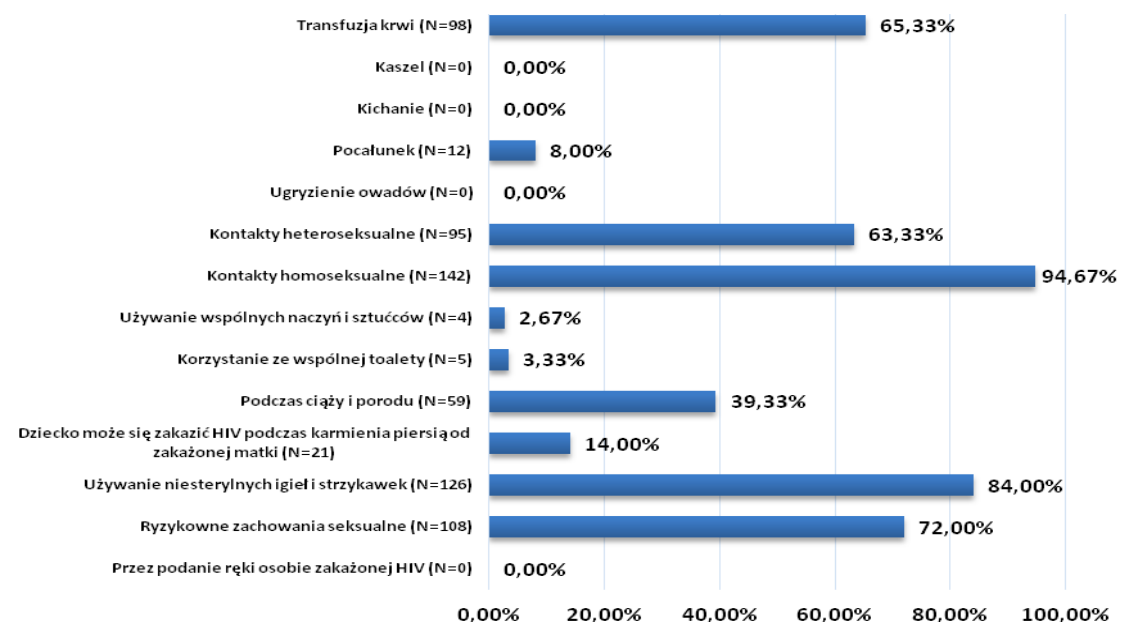

Rycina 4. Znajomość wśród badanych sytuacji, w jakich może dojść do zakażenia HIV.

Źródło: wynik badań własnych

Jako sytuacje, w jakich może dojść do zakażenia HIV zdecydowana większość badanych wymieniała: kontakty homoseksualne (94,67\%), używanie niesterylnych igieł i strzykawek 
(84,00\%), ryzykowne zachowania seksualne $(72,00 \%)$ oraz transfuzję krwi $(65,33 \%)$ i kontakty heteroseksualne $(63,33 \%)$. Ponadto, 39,33\% badanych wskazało również ciążę i poród, 14,00\% badanych odpowiednio karmienie piersią od zakażonej matki, 8,00\% badanych odpowiednio pocałunek, 3,33\% badanych - odpowiednio korzystanie ze wspólnej toalety, a 2,67\% badanych - odpowiednio używanie wspólnych naczyń i sztućców.

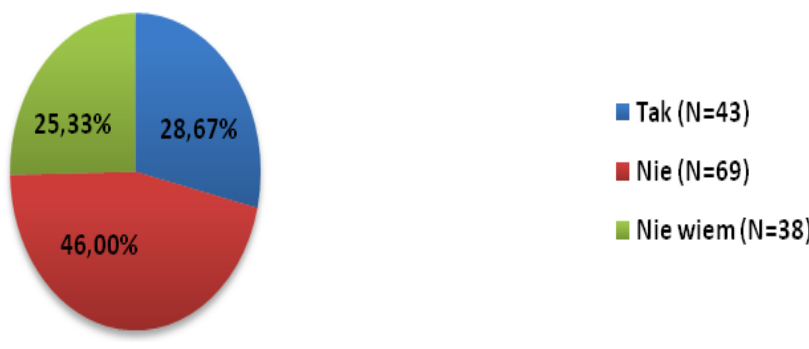

Rycina 5. Opinie badanych, że problem HIV dotyczy tylko osób podejmujących ryzykowne zachowania seksualne i narkomanów. Źródło: wynik badań własnych

Pod względem opinii, że problem HIV dotyczy tylko osób podejmujących ryzykowne zachowania seksualne i narkomanów, ankietowani byli dość podzieleni. Największy odsetek badanych był zdania, że problem HIV nie dotyczy tylko tych osób $(46,00 \%)$. Przeciwnego zdania było $28,67 \%$ badanych. Z kolei, co czwarty respondent $(25,33 \%)$ nie miał wiedzy w tym zakresie.

W pierwszej kolejności ocenie poddano związek między płcią, miejscem zamieszkania oraz wykształceniem badanych a poziomem ich wiedzy na temat HIV i AIDS. Pozwoliło to zweryfikować, czy poziom tej wiedzy różni się istotnie w grupach zróżnicowanych pod względem powyższych czynników socjodemograficznych. 


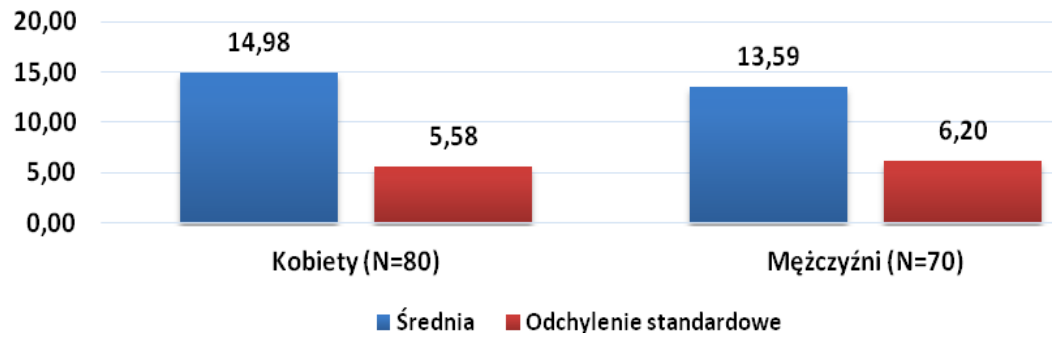

Rycina 6. Poziom wiedzy na temat HIV i AIDS w podziale na płeć badanych.

Źródło: wynik badań własnych

Tabela 1. Badanie istotności różnic $w$ poziomie wiedzy na temat HIV i AIDS $w$ grupach zróżnicowanych pod względem płci badanych.

\begin{tabular}{|c|c|c|c|c|}
\hline \multirow{2}{*}{\multicolumn{2}{|c|}{ Statystyki opisowe }} & \multicolumn{2}{|c|}{ Pleć } & \multirow{2}{*}{$\begin{array}{c}\text { Wyniki testu U Manna- } \\
\text { Whitneya }\end{array}$} \\
\hline & & Kobiety & Mężczyźni & \\
\hline \multicolumn{2}{|c|}{ Liczebność (N) } & 80 & 70 & \multirow{9}{*}{$Z=-1,482 ; p=0,138$} \\
\hline \multicolumn{2}{|c|}{ Średnia } & 14,98 & 13,59 & \\
\hline \multicolumn{2}{|c|}{$\begin{array}{c}\text { Odchylenie } \\
\text { standardowe }\end{array}$} & 5,58 & 6,20 & \\
\hline \multirow{2}{*}{$\begin{array}{l}\text { Poziom } \\
\text { ufności }\end{array}$} & $-95,00 \%$ & 13,73 & 12,11 & \\
\hline & $+95,00 \%$ & 16,22 & 15,06 & \\
\hline \multicolumn{2}{|c|}{ Mediana } & 14,50 & 13,00 & \\
\hline \multicolumn{2}{|c|}{ Minimum } & 5,00 & 2,00 & \\
\hline \multicolumn{2}{|c|}{ Maksimum } & 27,00 & 26,00 & \\
\hline \multicolumn{2}{|c|}{ Bląd standardowy } & 0,62 & 0,74 & \\
\hline
\end{tabular}

Źródło: wynik badań własnych

Kobiety i mężczyźni nie różnili się istotnie między sobą pod względem poziomu wiedzy na temat HIV i AIDS. Ilość prawidłowych 
odpowiedzi na pytania dotyczące tej wiedzy w grupie kobiet wynosił średnio 14,98, zaś w grupie mężczyzn - odpowiednio 13,59 (odchylenia standardowe wynosiły odpowiednio 5,58 i 6,20). Jakiekolwiek różnice pod tym względem między obiema grupami nie były znaczące. Potwierdzają to również wyniki testu U MannaWhitneya, które wskazują na brak istotnego statystycznie $(p>0,05)$ wpływu płci na poziom wiedzy na temat HIV i AIDS.

Tabela 2. Badanie istotności różnic $w$ poziomie wiedzy na temat HIV i AIDS w grupach zróżnicowanych pod względem miejsca zamieszkania badanych.

\begin{tabular}{|c|c|c|c|c|}
\hline \multirow{2}{*}{\multicolumn{2}{|c|}{ Statystyki opisowe }} & \multicolumn{2}{|c|}{ Miejsce zamieszkania } & \multirow{2}{*}{$\begin{array}{l}\text { Wyniki testu U } \\
\text { Manna-Whitneya }\end{array}$} \\
\hline & & Miasto & Wieś & \\
\hline \multicolumn{2}{|c|}{ Liczebność (N) } & 85 & 65 & \multirow{9}{*}{$\mathrm{Z}=3,360 ; p=0,001$} \\
\hline \multicolumn{2}{|l|}{ Średnia } & 15,87 & 12,31 & \\
\hline \multicolumn{2}{|c|}{$\begin{array}{l}\text { Odchylenie } \\
\text { standardowe }\end{array}$} & 6,08 & 5,01 & \\
\hline \multirow{2}{*}{$\begin{array}{l}\text { Poziom } \\
\text { ufności }\end{array}$} & $\begin{array}{c}- \\
95,00 \\
\%\end{array}$ & 14,56 & 11,07 & \\
\hline & $\begin{array}{c}+95,00 \\
\%\end{array}$ & 17,18 & 13,55 & \\
\hline \multicolumn{2}{|l|}{ Mediana } & 16,00 & 12,00 & \\
\hline \multicolumn{2}{|l|}{ Minimum } & 6,00 & 2,00 & \\
\hline \multicolumn{2}{|l|}{ Maksimum } & 27,00 & 24,00 & \\
\hline \multicolumn{2}{|c|}{ Błąd standardowy } & 0,66 & 0,62 & \\
\hline
\end{tabular}

Źródło: wynik badań własnych

Z kolei miejsce zamieszkania istotnie różnicowało poziom wiedzy badanych na temat HIV i AIDS. Mieszkańcy miasta udzielali znacznie więcej prawidłowych odpowiedzi na poszczególne pytania dotyczące wiedzy w tym zakresie (średnio 15,87), niż mieszkańcy wsi 
(odpowiednio 12,31) (odchylenia standardowe wynosiły odpowiednio 6,08 i 5,01). Różnice między obiema grupami były znaczące, co potwierdzają także wyniki testu U Manna-Whitneya. Zgodnie z tymi wynikami miejsce zamieszkania wpływa istotnie statystycznie $(p<0,01)$ na poziom wiedzy na temat HIV i AIDS. Takie wyniki oznaczają, iż mieszkańcy wsi wykazują istotnie wyższy poziom wiedzy w tym zakresie.

Tabela 3. Badanie istotności różnic $\mathrm{w}$ poziomie wiedzy na temat HIV i AIDS w grupach zróżnicowanych pod względem wykształcenia badanych.

\begin{tabular}{|c|c|c|c|c|c|}
\hline \multirow{2}{*}{\multicolumn{2}{|c|}{$\begin{array}{l}\text { Statystyki } \\
\text { opisowe }\end{array}$}} & \multicolumn{3}{|c|}{ Wykształcenie } & \multirow{2}{*}{$\begin{array}{l}\text { Wyniki } \\
\text { korelacji } \\
\text { porządk } \\
\text { u rang } \\
\text { Spearma } \\
\text { na }\end{array}$} \\
\hline & & Zawodowe & Średnie & Wyższe & \\
\hline \multicolumn{2}{|c|}{ Liczebność (N) } & 51 & 58 & 41 & \multirow{9}{*}{$\begin{array}{l}R=0,693 ; \\
t(N- \\
2)=11,71 \\
; \\
p=0,000\end{array}$} \\
\hline \multicolumn{2}{|l|}{ Średnia } & 9,82 & 13,83 & 20,63 & \\
\hline \multicolumn{2}{|c|}{$\begin{array}{l}\text { Odchylenie } \\
\text { standardowe }\end{array}$} & 3,86 & 4,14 & 4,41 & \\
\hline \multirow{2}{*}{$\begin{array}{l}\text { Poziom } \\
\text { ufności }\end{array}$} & $\begin{array}{l}- \\
95,00 \\
\%\end{array}$ & 8,74 & 12,74 & 19,24 & \\
\hline & $\begin{array}{l}+95,00 \\
\%\end{array}$ & 10,91 & 14,92 & 22,03 & \\
\hline \multicolumn{2}{|c|}{ Mediana } & 10,00 & 13,00 & 22,00 & \\
\hline \multicolumn{2}{|c|}{ Minimum } & 2,00 & 6,00 & 9,00 & \\
\hline \multicolumn{2}{|c|}{ Maksimum } & 19,00 & 22,00 & 27,00 & \\
\hline \multicolumn{2}{|c|}{ Błąd standardowy } & 0,54 & 0,54 & 0,69 & \\
\hline
\end{tabular}

Źródło: wynik badań własnych 
Również wykształcenie znacząco różnicowało poziom wiedzy badanych na temat HIV i AIDS. Jak wynika $\mathrm{z}$ powyższej tabeli i wykresu, wraz $\mathrm{z}$ poziomem wykształcenia rosła średnia ilość udzielonych prawidłowych odpowiedzi, a także rosła wartość odchylenia standardowego, (co oznacza coraz większe zróżnicowanie pod względem poziomu wiedzy $\mathrm{w}$ obrębie poszczególnych grup). Osoby z wykształceniem zawodowym udzieliły średnio 9,82 prawidłowych odpowiedzi, średnim - odpowiednio 13,83, zaś wyższym - odpowiednio 20,63. Z kolei, wartość odchylenia standardowego wynosiła $\mathrm{w}$ poszczególnych grupach odpowiednio 3,86; 4,14 i 4,41. Różnice między poszczególnymi grupami były bardzo duże. Potwierdzają to również wyniki korelacji porządku rang Spearmana, zgodnie z którymi, zachodzi istotny statystycznie $(\mathrm{p}<0,001)$ związek, między wykształceniem badanych a ich poziomem wiedzy na temat HIV i AIDS. Wyniki te wskazują, że im wyższy poziom wykształcenia badanych, tym większy poziom wiedzy posiadali w zakresie HIV i AIDS.

Tabela 4. Badanie istotności różnic w poziomie wiedzy na temat HIV i AIDS w grupach zróżnicowanych pod względem korzystania z prasy i czasopism, jako źródła informacji na temat HIV i AIDS.

\begin{tabular}{|c|c|c|c|c|}
\hline \multirow{2}{*}{\multicolumn{2}{|c|}{ Statystyki opisowe }} & \multicolumn{2}{|c|}{ Prasa / czasopisma } & \multirow{2}{*}{$\begin{array}{c}\text { Wyniki } \\
\text { testu U } \\
\text { Manna- } \\
\text { Whitneya }\end{array}$} \\
\hline & & Tak & Nie & \\
\hline \multicolumn{2}{|c|}{ Liczebność (N) } & 85 & 65 & \multirow{9}{*}{$\begin{array}{c}Z=1,773 ; \\
p=0,076\end{array}$} \\
\hline \multicolumn{2}{|c|}{ Śrrednia } & 13,46 & 15,46 & \\
\hline \multicolumn{2}{|c|}{ Odchylenie standardowe } & 5,01 & 6,76 & \\
\hline \multirow{2}{*}{$\begin{array}{l}\text { Poziom } \\
\text { ufności }\end{array}$} & $-95,00 \%$ & 12,38 & 13,79 & \\
\hline & $+95,00 \%$ & 14,54 & 17,14 & \\
\hline \multicolumn{2}{|c|}{ Mediana } & 13,00 & 16,00 & \\
\hline \multicolumn{2}{|c|}{ Minimum } & 4,00 & 2,00 & \\
\hline \multicolumn{2}{|c|}{ Maksimum } & 25,00 & 27,00 & \\
\hline \multicolumn{2}{|c|}{ Bląd standardowy } & 0,54 & 0,84 & \\
\hline
\end{tabular}

Źródło: wynik badań własnych 
Korzystanie z prasy lub czasopism nie wpływało istotnie na poziom wiedzy badanych na temat HIV i AIDS. Badani bez względu na to, czy korzystali $\mathrm{z}$ tego źródła informacji czy też nie, reprezentowali zbliżony poziom wiedzy $\mathrm{w}$ tym zakresie. Osoby korzystające $\mathrm{z}$ prasy lub czasopism średnio udzieliły 13,46 prawidłowych odpowiedzi (przy odchyleniu standardowym 5,01), zaś osoby niekorzystające $\mathrm{z}$ tego źródła informacji nieco więcej odpowiednio 15,46 (przy odchyleniu standardowym 6,76). Jakiekolwiek różnice pod tym względem między obiema grupami nie były znaczące. Potwierdzają to również wyniki testu U MannaWhitneya, które wskazują na brak istotnego statystycznie $(\mathrm{p}>0,05)$ wpływu korzystania z prasy i czasopism jako źródła informacji na temat HIV i AIDS na poziom wiedzy na temat HIV i AIDS.

Tabela 5. Badanie istotności różnic $w$ poziomie wiedzy na temat HIV i AIDS w grupach zróżnicowanych pod względem korzystania z Internetu, jako źródła informacji na temat HIV i AIDS.

\begin{tabular}{|c|c|c|c|c|}
\hline \multirow{2}{*}{\multicolumn{2}{|c|}{ Statystyki opisowe }} & \multicolumn{2}{|c|}{ Internet } & \multirow{2}{*}{$\begin{array}{c}\text { Wyniki } \\
\text { testu U } \\
\text { Manna- } \\
\text { Whitneya }\end{array}$} \\
\hline & & Tak & Nie & \\
\hline \multicolumn{2}{|c|}{ Liczebność (N) } & 114 & 36 & \multirow{9}{*}{$\begin{array}{l}\mathrm{Z}=1,067 ; \\
\mathrm{p}=0,286\end{array}$} \\
\hline \multicolumn{2}{|c|}{ Średnia } & 14,06 & 15,17 & \\
\hline \multicolumn{2}{|c|}{$\begin{array}{c}\text { Odchylenie } \\
\text { standardowe }\end{array}$} & 6,05 & 5,36 & \\
\hline \multirow{2}{*}{$\begin{array}{l}\text { Poziom } \\
\text { ufności }\end{array}$} & $-95,00 \%$ & 12,94 & 13,35 & \\
\hline & $+95,00 \%$ & 15,18 & 16,98 & \\
\hline \multicolumn{2}{|c|}{ Mediana } & 13,00 & 14,50 & \\
\hline \multicolumn{2}{|c|}{ Minimum } & 2,00 & 6,00 & \\
\hline \multicolumn{2}{|c|}{ Maksimum } & 27,00 & 26,00 & \\
\hline \multicolumn{2}{|c|}{ Blad standardowy } & 0,57 & 0,89 & \\
\hline
\end{tabular}

Źródło: wynik badań własnych 
Ponadto, korzystanie $\mathrm{z}$ Internetu nie wpływało istotnie na poziom wiedzy badanych na temat HIV i AIDS. Badani bez względu na to, czy korzystali $\mathrm{z}$ tego źródła informacji czy też nie, reprezentowali zbliżony poziom wiedzy $\mathrm{w}$ tym zakresie. Osoby korzystające $\mathrm{z}$ Internetu średnio udzieliły 14,06 prawidłowych odpowiedzi (przy odchyleniu standardowym 6,05), zaś osoby niekorzystające z tego źródła informacji nieco więcej - odpowiednio 15,17 (przy odchyleniu standardowym 5,36). Jakiekolwiek różnice pod tym względem między obiema grupami nie były znaczące. Potwierdzają to również wyniki testu U Manna-Whitneya, które wskazują na brak istotnego statystycznie $(\mathrm{p}>0,05)$ wpływu korzystania Internetu jako źródła informacji na temat HIV i AIDS na poziom wiedzy na temat HIV i AIDS.

Tabela 6. Badanie istotności różnic w poziomie wiedzy na temat HIV i AIDS w grupach zróżnicowanych pod względem korzystania z telewizji jako źródła informacji na temat HIV i AIDS.

\begin{tabular}{|c|c|c|c|c|}
\hline \multirow{2}{*}{\multicolumn{2}{|c|}{ Statystyki opisowe }} & \multicolumn{2}{|c|}{ Telewizja } & \multirow{2}{*}{$\begin{array}{c}\text { Wyniki } \\
\text { testu U } \\
\text { Manna- } \\
\text { Whitneya }\end{array}$} \\
\hline & & Tak & Nie & \\
\hline \multicolumn{2}{|c|}{ Liczebność (N) } & 97 & 53 & \multirow{9}{*}{$\begin{array}{c}Z=-2,481 \\
p=0,013\end{array}$} \\
\hline \multicolumn{2}{|c|}{ Średnia } & 13,44 & 15,94 & \\
\hline \multicolumn{2}{|c|}{ Odchylenie standardowe } & 5,58 & 6,17 & \\
\hline \multirow{2}{*}{$\begin{array}{l}\text { Poziom } \\
\text { ufności }\end{array}$} & $-95,00 \%$ & 12,32 & 14,24 & \\
\hline & $+95,00 \%$ & 14,57 & 17,64 & \\
\hline \multicolumn{2}{|c|}{ Mediana } & 12,00 & 16,00 & \\
\hline \multicolumn{2}{|c|}{ Minimum } & 4,00 & 2,00 & \\
\hline \multicolumn{2}{|c|}{ Maksimum } & 27,00 & 26,00 & \\
\hline \multicolumn{2}{|c|}{ Bląd standardowy } & 0,57 & 0,85 & \\
\hline
\end{tabular}

Źródło: wynik badań własnych 
Natomiast korzystanie z telewizji wpływało istotnie na poziom wiedzy badanych na temat HIV i AIDS. Badani korzystający z tego źródła informacji wykazywali niższy poziom wiedzy w zakresie HIV i AIDS. Osoby korzystające $\mathrm{z}$ telewizji średnio udzieliły 13,44 prawidłowych odpowiedzi (przy odchyleniu standardowym 5,58), zaś osoby niekorzystające z tego źródła informacji więcej - odpowiednio 15,94 (przy odchyleniu standardowym 6,17). Różnice pod tym względem między obiema grupami były znaczące. Potwierdzają to również wyniki testu $U$ Manna-Whitneya, zgodnie z którymi zachodzi istotny statystycznie $(\mathrm{p}<0,05)$ wpływ telewizji jako źródła informacji na temat HIV i AIDS na poziom wiedzy na temat HIV i AIDS. Takie wyniki wskazują, że korzystanie z telewizji jako źródła informacji na temat HIV i AIDS obniża istotnie poziom wiedzy w tym zakresie, a tym samym telewizja nie jest dobrym źródłem informacji na ten temat.

Tabela 7. Badanie istotności różnic w poziomie wiedzy na temat HIV i AIDS w grupach zróżnicowanych pod względem korzystania ze znajomych, jako źródła informacji na temat HIV i AIDS.

\begin{tabular}{|c|c|c|c|c|}
\hline \multirow{2}{*}{\multicolumn{2}{|c|}{ Statystyki opisowe }} & \multicolumn{2}{|c|}{ Znajomi } & \multirow{2}{*}{$\begin{array}{c}\text { Wyniki } \\
\text { testu U } \\
\text { Manna- } \\
\text { Whitneya }\end{array}$} \\
\hline & & Tak & Nie & \\
\hline \multicolumn{2}{|c|}{ Liczebność (N) } & 34 & 116 & \multirow{8}{*}{$\begin{array}{c}Z=3,658 \\
p=0,000\end{array}$} \\
\hline \multicolumn{2}{|l|}{ Średnia } & 11,09 & 15,28 & \\
\hline \multicolumn{2}{|c|}{ Odchylenie standardowe } & 5,05 & 5,81 & \\
\hline \multirow{2}{*}{$\begin{array}{l}\text { Poziom } \\
\text { ufności }\end{array}$} & $-95,00 \%$ & 9,33 & 14,21 & \\
\hline & $+95,00 \%$ & 12,85 & 16,34 & \\
\hline \multicolumn{2}{|c|}{ Mediana } & 10,00 & 15,00 & \\
\hline \multicolumn{2}{|c|}{ Minimum } & 2,00 & 4,00 & \\
\hline \multicolumn{2}{|c|}{ Maksimum } & 23,00 & 27,00 & \\
\hline
\end{tabular}




\begin{tabular}{|l|l|l|l|}
\hline Błąd standardowy & 0,87 & 0,54 & \\
\hline
\end{tabular}

Źródło: wynik badań własnych

Korzystanie z wiedzy znajomych również wpływało istotnie na poziom wiedzy badanych na temat HIV i AIDS. Badani korzystający z tego źródła informacji wykazywali znacznie niższy poziom wiedzy w zakresie HIV i AIDS. Osoby korzystające ze znajomych jako źródła informacji średnio udzieliły 11,09 prawidłowych odpowiedzi (przy odchyleniu standardowym 5,05), zaś osoby niekorzystające $\mathrm{z}$ tego źródła informacji znacznie więcej - odpowiednio 15,28 (przy odchyleniu standardowym 5,81). Różnice pod tym względem między obiema grupami były znaczące. Potwierdzają to również wyniki testu U Manna-Whitneya, zgodnie z którymi zachodzi istotny statystycznie $(p<0,001)$ wpływ znajomych jako źródła informacji na temat HIV i AIDS

na poziom wiedzy na temat HIV i AIDS. Tak jak w przypadku telewizji, wyniki te wskazują, że korzystanie z wiedzy znajomych jako źródła informacji na temat HIV i AIDS obniża istotnie poziom wiedzy w tym zakresie, a tym samym znajomi nie są dobrym źródłem informacji na ten temat.

Tabela 8. Badanie istotności różnic w poziomie wiedzy na temat HIV i AIDS w grupach zróżnicowanych pod względem korzystania z literatury, jako źródła informacji na temat HIV i AIDS.

\begin{tabular}{|c|c|c|c|c|}
\hline \multirow{2}{*}{\multicolumn{2}{|c|}{ Statystyki opisowe }} & \multicolumn{2}{|c|}{ Literatura } & \multirow{2}{*}{$\begin{array}{c}\text { Wyniki } \\
\text { testu U } \\
\text { Manna- } \\
\text { Whitneya } \\
\end{array}$} \\
\hline & & Tak & Nie & \\
\hline \multicolumn{2}{|c|}{ Liczebność (N) } & 48 & 102 & \multirow{4}{*}{$\begin{array}{c}Z=6,811 ; \\
p=0,000\end{array}$} \\
\hline Średnia & & 19,33 & 11,97 & \\
\hline \multicolumn{2}{|c|}{ Odchylenie standardowe } & 5,25 & 4,58 & \\
\hline Poziom & $-95,00 \%$ & 17,81 & 11,07 & \\
\hline
\end{tabular}




\begin{tabular}{|c|c|c|c|}
\hline ufności & $+95,00 \%$ & 20,86 & 12,87 \\
\hline \multicolumn{2}{|c|}{ Mediana } & 20,50 & 12,00 \\
\hline \multicolumn{2}{|c|}{ Minimum } & 8,00 & 2,00 \\
\hline \multicolumn{2}{|c|}{ Maksimum } & 27,00 & 23,00 \\
\hline \multicolumn{2}{|c|}{ Bląd standardowy } & 0,76 & 0,45 \\
\hline
\end{tabular}

Źródło: wynik badań własnych

Również korzystanie z literatury wpływało istotnie na poziom wiedzy badanych na temat HIV i AIDS. Badani korzystający $\mathrm{z}$ tego źródła informacji wykazywali znacznie wyższy poziom wiedzy w zakresie HIV i AIDS. Osoby korzystające z literatury jako źródła informacji średnio udzieliły 19,33 prawidłowych odpowiedzi (przy odchyleniu standardowym 5,25), zaś osoby nie korzystające $\mathrm{z}$ tego źródła informacji znacznie mniej - odpowiednio 11,97 (przy odchyleniu standardowym 4,58). Różnice pod tym względem między obiema grupami były znaczące. Potwierdzają to również wyniki testu U Manna-Whitneya, zgodnie z którymi zachodzi istotny statystycznie $(\mathrm{p}<0,001)$ wpływ literatury jako źródła informacji na temat HIV i AIDS na poziom wiedzy na temat HIV i AIDS. Takie wyniki wskazują, że korzystanie z literatury jako źródła informacji na temat HIV i AIDS podwyższa istotnie poziom wiedzy $\mathrm{w}$ tym zakresie, a tym samym literatura jest dobrym źródłem informacji na ten temat.

Tabela 9. Badanie istotności różnic w poziomie wiedzy na temat HIV i AIDS w grupach zróżnicowanych pod względem korzystania z kampanii społecznych, jako źródła informacji na temat HIV i AIDS.

\begin{tabular}{|c|c|c|c|c|}
\hline \multirow{2}{*}{\multicolumn{2}{|c|}{ Statystyki opisowe }} & \multicolumn{2}{|c|}{ Kampanie społeczne } & \multirow{2}{*}{$\begin{array}{c}\text { Wyniki testu U } \\
\text { Manna- } \\
\text { Whitneya }\end{array}$} \\
\hline & & Tak & Nie & \\
\hline Liczebno & & 39 & 111 & \multirow{4}{*}{$\begin{array}{c}Z=-7,408 \\
p=0,000\end{array}$} \\
\hline Średnia & & 20,64 & 12,11 & \\
\hline \multicolumn{2}{|c|}{ Odchylenie standardowe } & 4,43 & 4,61 & \\
\hline Poziom & $-95,00 \%$ & 19,21 & 11,24 & \\
\hline
\end{tabular}




\begin{tabular}{|c|c|c|}
\hline$+95,00 \%$ & 22,08 & 12,97 \\
\hline Mediana & 21,00 & 12,00 \\
\hline Minimum & 9,00 & 2,00 \\
\hline Maksimum & 27,00 & 24,00 \\
\hline Błąd standardowy & 0,71 & 0,44 \\
\hline
\end{tabular}

Źródło: wynik badań własnych

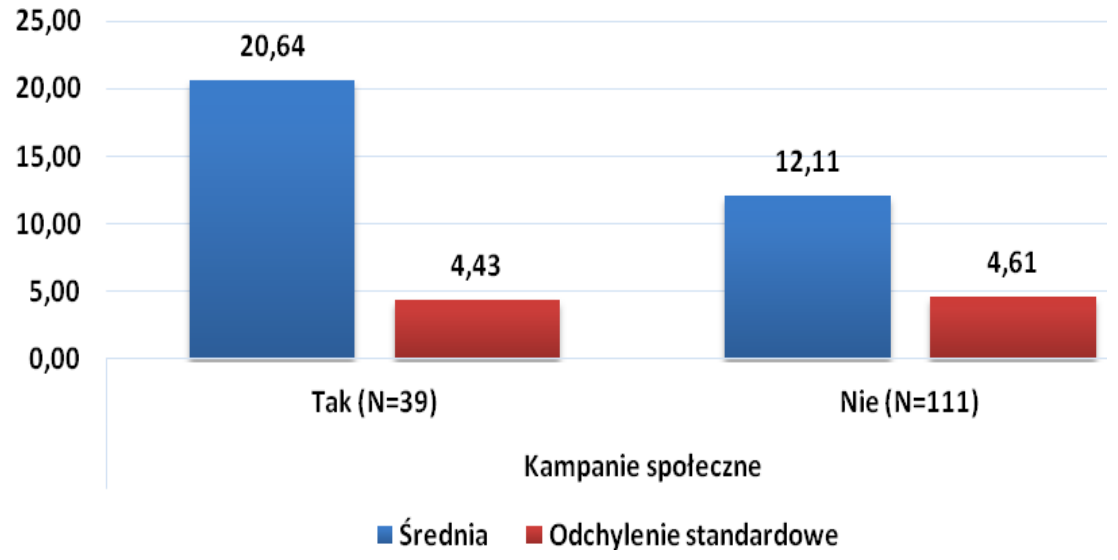

Rycina 7. Poziom wiedzy na temat HIV i AIDS $w$ podziale na korzystanie z kampanii społecznych jako źródła informacji na temat HIV i AIDS.

Źródło: wynik badań własnych

Ponadto, korzystanie $\mathrm{z}$ informacji przekazywanych w kampaniach społecznych wpływało istotnie na poziom wiedzy badanych na temat HIV i AIDS. Badani korzystający z tego źródła informacji wykazywali znacznie wyższy poziom wiedzy w zakresie HIV i AIDS. Osoby korzystające z kampanii społecznych jako źródła informacji średnio udzieliły 20,64 prawidłowych odpowiedzi (przy odchyleniu standardowym 4,43), zaś osoby nie korzystające $\mathrm{z}$ tego źródła informacji znacznie mniej - odpowiednio 12,11 (przy odchyleniu standardowym 4,61). Różnice pod tym względem między obiema grupami były znaczące. Potwierdzają to również wyniki testu U Manna-Whitneya, zgodnie z którymi zachodzi istotny statystycznie 
( $\mathrm{p}<0,001)$ wpływ kampanii społecznych jako źródła informacji na temat HIV i AIDS na poziom wiedzy na temat HIV i AIDS. Podobnie jak w przypadku literatury, wyniki te wskazują, że korzystanie z kampanii społecznych jako źródła informacji na temat HIV i AIDS podwyższa istotnie poziom wiedzy $\mathrm{w}$ tym zakresie, a tym samym kampanie społeczne są dobrym źródłem informacji na ten temat.

Tabela 10. Badanie istotności różnic $w$ poziomie wiedzy na temat HIV i AIDS w grupach zróżnicowanych pod względem korzystania z uczelni i szkoły, jako źródła informacji na temat HIV i AIDS.

\begin{tabular}{|c|c|c|c|c|}
\hline \multirow{2}{*}{\multicolumn{2}{|c|}{ Statystyki opisowe }} & \multicolumn{2}{|c|}{ Uczelnia /szkoła } & \multirow{2}{*}{$\begin{array}{l}\text { Wyniki testu } \\
\text { U Manna- } \\
\text { Whitneya }\end{array}$} \\
\hline & & Tak & Nie & \\
\hline \multicolumn{2}{|c|}{ Liczebność (N) } & 36 & 114 & \multirow{9}{*}{$\begin{array}{c}\mathrm{Z}=-\mathbf{4 , 0 7 3} \\
\mathrm{p}=\mathbf{0 , 0 0 0}\end{array}$} \\
\hline \multicolumn{2}{|c|}{ Średnia } & 17,67 & 13,27 & \\
\hline \multicolumn{2}{|c|}{ Odchylenie standardowe } & 4,80 & 5,83 & \\
\hline \multirow{2}{*}{$\begin{array}{l}\text { Poziom } \\
\text { ufności }\end{array}$} & $-95,00 \%$ & 16,04 & 12,19 & \\
\hline & $+95,00 \%$ & 19,29 & 14,35 & \\
\hline \multicolumn{2}{|c|}{ Mediana } & 17,50 & 12,00 & \\
\hline \multicolumn{2}{|c|}{ Minimum } & 10,00 & 2,00 & \\
\hline \multicolumn{2}{|c|}{ Maksimum } & 27,00 & 26,00 & \\
\hline \multicolumn{2}{|c|}{ Bląd standardowy } & 0,80 & 0,55 & \\
\hline
\end{tabular}

Źródło: wynik badań własnych 


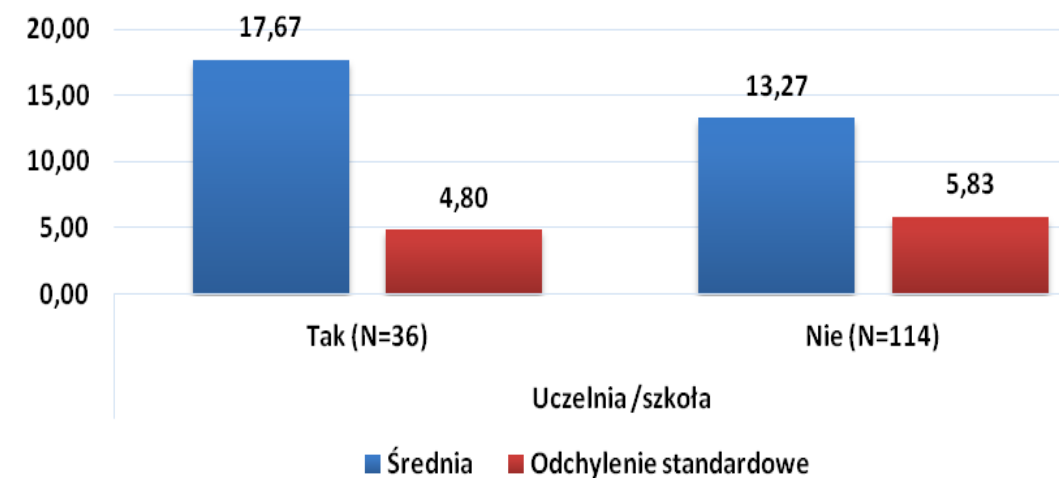

Rycina 8. Poziom wiedzy na temat HIV i AIDS w podziale na korzystanie $\mathrm{z}$ uczelni i szkoły, jako źródła informacji na temat HIV i AIDS.

Źródło: wynik badań własnych

Korzystanie z informacji przekazywanych na uczelniach lub w szkołach także wpływało istotnie na poziom wiedzy badanych na temat HIV i AIDS. Badani korzystający z tego źródła informacji wykazywali znacznie wyższy poziom wiedzy w zakresie HIV i AIDS. Osoby korzystające z uczelni lub szkół jako źródła informacji średnio udzieliły 17,67 prawidłowych odpowiedzi (przy odchyleniu standardowym 4,80), zaś osoby niekorzystające $\mathrm{z}$ tego źródła informacji znacznie mniej - odpowiednio 13,27 (przy odchyleniu standardowym 5,83). Różnice pod tym względem między obiema grupami były znaczące. Potwierdzają to również wyniki testu U Manna-Whitneya, zgodnie z którymi zachodzi istotny statystycznie $(\mathrm{p}<0,001)$ wpływ kampanii społecznych jako źródła informacji na temat HIV i AIDS na poziom wiedzy na temat HIV i AIDS. Podobnie jak w przypadku literatury i kampanii społecznych, wyniki te wskazują, że korzystanie $\mathrm{z}$ kampanii społecznych jako źródła informacji na temat HIV i AIDS podwyższa istotnie poziom wiedzy $w$ tym zakresie, a tym samym kampanie społeczne są dobrym źródłem informacji na ten temat. 
Tabela 11. Badanie istotności różnic $w$ poziomie wiedzy na temat HIV i AIDS w grupach zróżnicowanych pod względem korzystania z ulotek jako źródła informacji na temat HIV i AIDS.

\begin{tabular}{|c|c|c|c|c|}
\hline \multirow{2}{*}{\multicolumn{2}{|c|}{ Statystyki opisowe }} & \multicolumn{2}{|c|}{ Ulotki } & \multirow{2}{*}{$\begin{array}{l}\text { Wyniki testu } \\
\text { U Manna- } \\
\text { Whitneya }\end{array}$} \\
\hline & & Tak & Nie & \\
\hline \multicolumn{2}{|c|}{ Liczebność (N) } & 22 & 128 & \multirow{9}{*}{$\mathrm{Z}=-3,121 ; p=0,002$} \\
\hline \multicolumn{2}{|l|}{ Średnia } & 17,95 & 13,70 & \\
\hline \multicolumn{2}{|c|}{ Odchylenie standardowe } & 5,30 & 5,79 & \\
\hline \multirow{2}{*}{$\begin{array}{l}\text { Poziom } \\
\text { ufności }\end{array}$} & $-95,00 \%$ & 15,60 & 12,69 & \\
\hline & $+95,00 \%$ & 20,31 & 14,72 & \\
\hline \multicolumn{2}{|c|}{ Mediana } & 18,50 & 13,00 & \\
\hline \multicolumn{2}{|c|}{ Minimum } & 8,00 & 2,00 & \\
\hline \multicolumn{2}{|c|}{ Maksimum } & 26,00 & 27,00 & \\
\hline \multicolumn{2}{|c|}{ Błąd standardowy } & 1,13 & 0,51 & \\
\hline
\end{tabular}

Źródło: wynik badań własnych

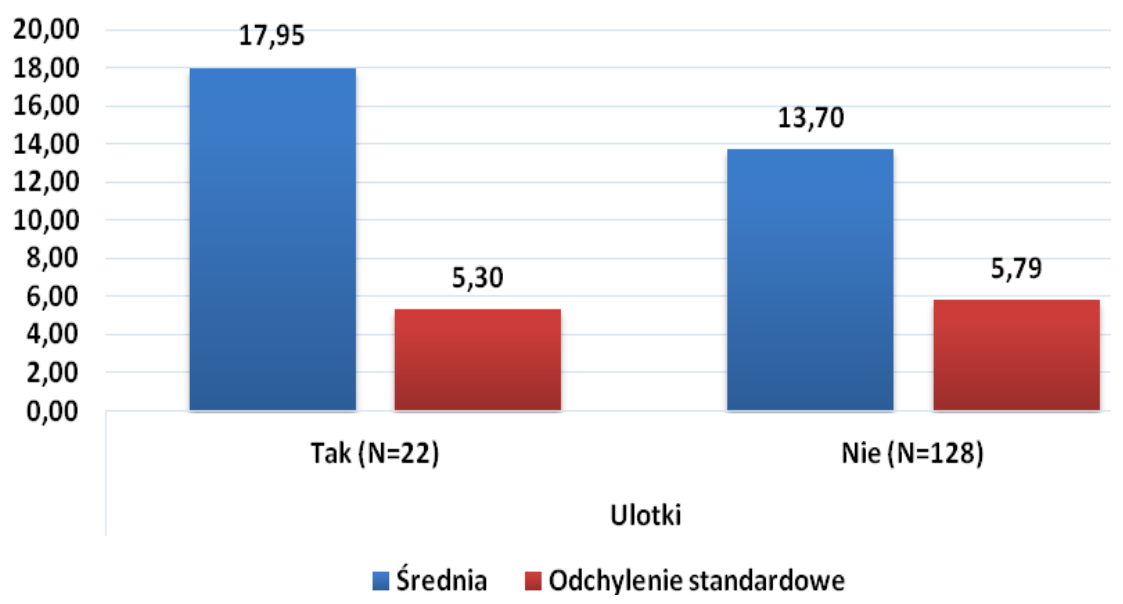


Rycina 9. Poziom wiedzy na temat HIV i AIDS $w$ podziale na korzystanie $z$ ulotek, jako źródła informacji na temat HIV i AIDS.

Źródło: wynik badań własnych

Ponadto, korzystanie z informacji przekazywanych na ulotkach również wpływało istotnie na poziom wiedzy badanych na temat HIV i AIDS. Badani korzystający z tego źródła informacji wykazywali znacznie wyższy poziom wiedzy w zakresie HIV i AIDS. Osoby korzystające z ulotek jako źródła informacji średnio udzieliły 17,95 prawidłowych odpowiedzi (przy odchyleniu standardowym 5,30), zaś osoby niekorzystające $\mathrm{z}$ tego źródła informacji znacznie mniej odpowiednio 13,70 (przy odchyleniu standardowym 5,79). Różnice pod tym względem między obiema grupami były znaczące. Potwierdzają to również wyniki testu U Manna-Whitneya, zgodnie z którymi zachodzi istotny statystycznie $(\mathrm{p}<0,01)$ wpływ ulotek jako źródła informacji na temat HIV i AIDS na poziom wiedzy na temat HIV i AIDS. Podobnie jak w przypadku literatury, kampanii społecznych oraz uczelni i szkół, wyniki te wskazują, że korzystanie z ulotek jako źródła informacji na temat HIV i AIDS podwyższa istotnie poziom wiedzy w tym zakresie, a tym samym ulotki są dobrym źródłem informacji na ten temat.

\section{Dyskusja}

Grupę badawczą stanowiło 150 osób, w wieku 19 - 49 lat. 80 kobiet i 70 mężczyzn zostało poddanych badaniu przy użyciu kwestionariusza ankiety, gdzie udzielili anonimowych odpowiedzi na 30 pytań. Większość badanych to mieszkańcy miasta Bełchatowa (56,67\%), a wsi 43,33\% ankietowanych. Najwięcej było osób z wykształceniem średnim - 38,67\%. Niewiele mniejsza grupa posiadała wykształcenie zawodowe - 34\%. Wyższe wykształcenie posiadało $27,33 \%$ badanych. 
Wyniki badań własnych wykazały, że wiedza badanych mieszkańców powiatu bełchatowskiego na temat HIV/AIDS jest na poziomie umiarkowanym, ale w niektórych aspektach nadal jest to wiedza niekompletna. Średnio udzielono 53,07\% prawidłowych odpowiedzi na pytania dotyczące kwestii związanych z HIV i AIDS. Skrót HIV prawidłowo rozwinęło tylko 38,67\% ankietowanych, to ponad dwukrotnie niższy wynik jaki uzyskał w 2016 roku Szymusiak, Rzepka i Hładki [8], gdzie skrót HIV prawidłowo rozpoznało $84 \%$ badanych.

Przeważająca liczba badanych nie potrafi rozwinąć skrótu AIDS, a tylko 25,33\% respondentów udzieliło prawidłowej odpowiedzi, to również ponad dwukrotnie mniejszy wynik, niż w 2016 roku uzyskał Szymusiak, Rzepka i Hładki [8] gdzie skrót AIDS prawidłowo rozwinęło 55\% ankietowanych.

Na dosyć dobrym poziomie jest wiedza badanych mieszkańców powiatu bełchatowskiego na temat podstawowych dróg szerzenia się wirusa HIV. 84\% ankietowanych wie, że HIV można zarazić się przez używanie niesterylnych igieł i strzykawek, a 72\% podaje jako źródła zakażenia ryzykowne zachowania seksualne, 94,67\% - kontakty homoseksualne, 63,33\% - kontakty heteroseksualne. Zdecydowanie mniej ankietowanych wie, że do zakażenia HIV może dojść podczas ciąży i porodu, a tylko $14 \%$ badanych ma świadomość, że mleko kobiece jest zakaźne i jest źródłem zakażenia dla dziecka w sytuacji karmienia piersią przez zakażoną HIV matkę. Transfuzji krwi obawia się 65,33\% badanych.

Pozytywnym zjawiskiem jest niewielki odsetek respondentów 3,33\% który, uważa że korzystanie ze wspólnej toalety może mieć wpływ na zakażenie wirusem HIV. Jest to wynik prawie dwunastokrotnie niższy, niż uzyskany przez Wołowskiego i Kasperowicz w 2012 roku, gdzie 38,33\% badanych uważało podobnie i sześciokrotnie niższy niż uzyskany przez Dyk w 2008 roku, gdzie $20 \%$ ankietowanych było podobnego zdania. 0 tym że używanie wspólnych naczyń i sztućców może mieć wpływ na zakażenie HIV jest 
przekonanych $2,67 \%$ ankietowanych, natomiast $8 \%$ uważa, że pocałunek stwarza ryzyko zakażenia HIV.

Pocieszający jest fakt, że nikt z badanych osób nie uważa, że do zakażenia wirusem HIV może dojść drogą kropelkową poprzez kaszel lub kichanie. Również nie zaobserwowano jakoby nadal żywy był mit, iż zakażenie HIV może być przenoszone poprzez ugryzienie owadów nikt $\mathrm{z}$ ankietowanych nie zaznaczył takiej odpowiedzi. To ponad szesnastokrotnie mniejszy wynik niż uzyskany w 2003 roku przez Hejwosz i Wiese [9], gdzie wówczas 16,5\% respondentów uważało, że zakażenie HIV przenoszone jest przez owady.

Na podstawie uzyskanych wyników badań własnych widoczne jest, że mimo coraz większej świadomości społecznej, ciągle występują stereotypy dotyczące HIV/AIDS powszechnie odbierane za fakty np.: dotyczą grup ryzyka. Ankietowani byli dość podzieleni pod względem opinii, kogo dotyczy zakażenie wirusem HIV.

O tym, że problem HIV/AIDS dotyczy tylko osób podejmujących ryzykowne zachowania seksualne i narkomanów przekonanych jest $28,67 \%$ badanych. Jest to czterokrotnie wyższy wynik niż uzyskany przez Wołowskiego i Kasperowicz w 2012 roku [10], gdzie podobnego zdania było $7 \%$ respondentów. Co czwarty mieszkaniec powiatu bełchatowskiego nie miał wiedzy w tym zakresie.

Zdecydowana większość badanych ma świadomość, że wirus HIV niszczy układ odpornościowy, stanowią oni 83,33\% ankietowanych, to wyższy wynik niż uzyskany w 2012 roku przez Wołowskiego i Kasperowicz [10], gdzie 67,5\% ankietowanych uważała podobnie.

Ankietowanym nie sprawiło większej trudności pytanie dotyczące szczepionki przeciw HIV/AIDS. Przeważająca większość respondentów $90 \%$ ma świadomość, że taka szczepionka nie istnieje. Błędnej odpowiedzi - że istnieje taka szczepionka udzieliło tylko $5,33 \%$ badanych, a $4,67 \%$ było zdania że istnieje szczepionka, ale tylko przeciw HIV. W 2012 roku Wołowski i Kasperowicz [10] uzyskali 
podobny wynik - 7,5\% badanych było przekonanych że istnieje szczepionka przeciw HIV/AIDS.

97,33\% ankietowanych uznało, że kontakty seksualne z wieloma partnerami to najryzykowniejsze pod kątem możliwości zakażenia się HIV zachowania seksualne. W badaniach Wołowskiego i Kasperowicz [10] z 2012 roku 90\% badanych miała podobne zdanie. Podobne rezultaty w 2005 roku uzyskali Pytka i Krupniewicz $(97,2 \%)$ [11]. Nieco niższy wynik w 2008 roku otrzymała Dyk - 80\%. Wydaje się, że takie ryzykowne zachowania znane są ankietowanym, jednak nie potrafią oni określić rozmiaru niebezpieczeństwa związanego z innymi ryzykownymi zachowaniami seksualnymi. 61,33\% ankietowanych $\mathrm{w}$ badaniach własnych wskazuje, jako ryzykowne zachowanie seksualne - seks bez prezerwatywy oraz stosunek analny - 53,33\%. Tylko 8\% respondentów uważa, że pocałunek z osobą zakażoną HIV to ryzykowne zachowanie mające wpływ na transmisję wirusa. Szymusiak, Rzepka i Hładki w 2016 roku uzyskali wyższy wynik - 13\% respondentów uważało, że pocałunek ma wpływ na zakażenie HIV.

Wiedza badanych na temat równego ryzyka zakażenia HIV wśród kobiet i mężczyzn w kontaktach seksualnych jest niewystarczająca. Większość badanych - 55,33\% uważa, że ryzyko zakażenia HIV w kontaktach seksualnych jest takie samo dla kobiet jak i dla mężczyzn. Tylko $10 \%$ respondentów prawidłowo wskazało, że ryzyko to jest większe dla kobiet. Dwukrotnie wyższy wynik uzyskał Szymusiak, Rzepka i Hładki [8], gdzie 20\% zaznaczyło prawidłową odpowiedź.

Co czwarty respondent w badaniach własnych oceniał, że wie, czym jest HIV i AIDS i jednocześnie uważał, że ten problem go nie dotyczy. 36\% badanych uważa, że wie jak chronić siebie i innych przed HIV i AIDS. Niewiele mniejszy odsetek badanych 27,33\% ma sporo wątpliwości i przyznaje, że nie wie jak chronić się przed HIV/AIDS.

Utrwalone postawy są oporne na zmiany, ale to nie znaczy, że nie można ich zmienić. HIV/AIDS nie należy demonizować, ani też 
bagatelizować. Cała świadomość społeczna dotycząca tego problemu powinna opierać się na naukowych faktach, oraz pozytywnych postawach wobec nosicieli HIV i chorych na AIDS.

Najwięcej wiedzy respondenci czerpią $\mathrm{z}$ mediów, a więc informacje tam zamieszczane powinny być wiarygodne. Jednak w naszym kraju ciągle mało jest programów edukacyjnych dotyczących profilaktyki HIV. Ciągle w Polsce jest zbyt mało kampanii i reklam poruszających problem HIV i AIDS.

Wiedza dotycząca HIV/AIDS wśród dorosłych osób jest bardzo zróżnicowana. Poziom wiedzy uzależniony jest od wykształcenia oraz miejsca zamieszkania. Najlepiej wypada na tle badań własnych znajomość dróg zakażenia. Edukację w zakresie HIV/AIDS, jako profilaktykę należy dostosować do poziomu wiedzy ogólnej przy uwzględnieniu najnowszych wyników badań oraz danych statystycznych.

Epidemia AIDS dotyka szczególnie młodych ludzi, zwłaszcza podejmujących ryzykowne zachowania seksualne. Z punktu widzenia zdrowia publicznego młodzi ludzie to bardzo ważna grupa populacji. Wtedy też kształtuje się wiele zachowań zdrowotnych. Takie zachowania

w dorosłym życiu często decydują o zdrowiu i długości dalszego życia.

Celem badań była ocena poziomu wiedzy społecznych mieszkańców powiatu bełchatowskiego w grupie wiekowej 19 - 49 lat, dotyczącej problematyki HIV i AIDS. Jest to bardzo istotny problem, ponieważ statystyki alarmują, że stale wzrasta ilość osób zakażonych HIV. Edukację należy rozpocząć już w szkole, bo wtedy jest szansa, że młodzi ludzie wkroczą w dorosłe życie, jako osoby odpowiedzialne za zdrowie swoje i innych. Badania wyraźnie wskazują, że istnieje konieczność promowania w środowiskach wiejskich wiedzy na temat bezpiecznego seksu, oswojenia społeczeństwa wiejskiego z problemem HIV/AIDS, który jest ciągle tematem tabu. Istnieje konieczność wprowadzenia programów profilaktycznych w środowisku wiejskim. 
Powyższe badania pokazują, że należy położyć większy nacisk na propagowanie wiedzy o HIV/AIDS, zwracając szczególną uwagę na możliwości zachowania się $w$ różnych sytuacjach, które mogą stwarzać ryzyko zakażenia.

\section{Wnioski}

- Wiedza badanych na temat HIV i AIDS była na poziomie umiarkowanym. Badani średnio udzielali 53,07\% prawidłowych odpowiedzi na pytania dotyczące różnych kwestii związanych z HIV i AIDS.

- Źródłami informacji, z jakich badani poznawali temat HIV i AIDS, najczęściej były: Internet, telewizja oraz prasa i czasopisma. W przypadku Internetu oraz prasy i czasopism nie zanotowano istotnego wpływu na poziom wiedzy badanych na temat HIV i AIDS. Natomiast telewizja istotnie obniżała poziom tej wiedzy i tym samym nie była dobrym źródłem informacji na ten temat. Taki sam wpływ na poziom wiedzy w zakresie HIV i AIDS mieli znajomi, którzy również istotnie obniżali poziom wiedzy na ten temat. Z kolei, wszystkie pozostałe źródła informacji (tj. literatura, kampanie społeczne, uczelnie i szkoły oraz ulotki) istotnie poprawiały poziom wiedzy w tym zakresie, a tym samym stanowiły dobre źródło informacji na ten temat.

- Kobiety i mężczyźni nie różnili się istotnie między sobą pod względem wiedzy na temat HIV i AIDS, a tym samym płeć nie wpływała istotnie na poziom tej wiedzy.

- Miejsce zamieszkania wpływało istotnie na poziomie wiedzy na temat HIV i AIDS. Mieszkańcy miasta wykazywali istotnie wyższy poziom wiedzy w tym zakresie.

- Poziom wiedzy na temat HIV i AIDS zależny był również od wykształcenia badanych. Im wyższy był poziom 
wykształcenia badanych, tym posiadali oni większy poziom wiedzy w zakresie HIV i AIDS.

\section{Zalecenia dla praktyki pielęgniarskiej}

Mimo, iż $w$ ciągu ostatnich 35 lat zrobiono bardzo dużo w poznaniu i leczeniu zakażeń HIV, oraz wywoływanego przez niego AIDS, to wciąż nie są to działania wystarczające. Postęp, który dokonał się w zakresie terapii antyretrowirusowej dotyczy głównie krajów rozwiniętych. Kraje biedne nadal borykają się z ogromną epidemią zachorowań na AIDS. W przypadku zakażenia ważne jest podjęcie terapii antyretrowirusowej, a także edukacja społeczeństwa na temat przeciwdziałania zakażeniom. Jest to związane z nakładem dużych środków finansowych, jednak bez takiego działania całkowite wyeliminowanie wirusa wydaje się niemożliwe.

Statystyki pokazują, że w Polsce każdego dnia dwie osoby dowiadują się o swoim zakażeniu. Odsetek ten mógłby być niższy, gdyby stosowano odpowiednią profilaktykę. Społeczeństwo, a zwłaszcza ludzie młodzi nie mają podstawowej wiedzy na temat HIV/AIDS i nie odnoszą do siebie możliwości zakażenia. Polacy mają małe poczucie zagrożenia HIV/AIDS, a to niestety sprzyja ryzykownym zachowaniom.

Obecnie coraz rzadziej i coraz mniej mówi się o HIV, wirus nie jest już sensacją. W naszym społeczeństwie nadal panuje przeświadczenie, że "ten problem mnie nie dotyczy”. Nie zdajemy sobie sprawy z tego, że wszyscy jesteśmy jedną grupą ryzyka. Wiele osób nie widzi potencjalnego zagrożenia związanego $\mathrm{z}$ ryzykownym zachowaniem oraz możliwością zakażenia się HIV w przeszłości.

Po analizie wyników badań, widać wyraźnie, że w edukacji jest cały czas dużo do zrobienia. Niezwykle ważna jest także edukacja na tematy dotyczące uzależnień od środków odurzających. Ciągle rośnie liczba osób zakażonych HIV i w następstwie chorych na AIDS. Każdy bez względu na wyznanie religijne czy też orientację seksualną 
może zostać zakażony wirusem HIV. Z tego powodu wiedza dotycząca HIV/AIDS jest niezbędna każdemu z nas.

\section{Bibliografia / Bibliography:}

1. Gładysz A. i wsp. Patogeneza, klinika i zakażenia oportunistyczne. W: Cianciara J., Juszczyk J. (Red.) Choroby zakaźne i pasożytnicze. Czelej, Lublin 2012;500-506.

2. Gąsiorowski J., Knysz B, Gładysz A. Zespół nabytego niedoboru odporności (AIDS). W: Gajewski P. Szczeklik A. (Red.) Interna Szczeklika 2013. Medycyna Praktyczna, Kraków 2013: 2344 - 2356.

3. Rogala M.: Historia i rozwój badań nad HIV i AIDS. Wiadomości Lekarskie 2011; 64 (4):255-256.

4. Ankiersztejn - Bartczak M. Psychospołeczna sytuacja osób żyjących z HIV i chorych na AIDS w Polsce. Praca doktorska. UW, Warszawa 2013, 8-52.

5. Jabłecki J., Arendarczyk M. Fenomeny epidemiologiczne zakażeń HIV/AIDS. Nowiny Lekarskie. 2006;75 (1):70-74.

6. Górecki W.: Zakażenia ludzkim wirusem upośledzenia odporności. Chirurgia Dziecięca. 2004; 1, 23-29.

7. Gładysz A. (Red.) Zakażenia HIV/AIDS poradnik dla lekarzy praktyków. Continuo, Wrocław 2007:11.

8. Szymusiak A., Rzepka E., Hładki W.: Poziom wiedzy na temat HIV i AIDS wśród społeczeństwa. Ostry Dyżur. 2015; 8, 4: 108-112.

9. Hejwosz D. A., Wiese J.: Poziom wiedzy na temat AIDS i HIV wśród licealistów i studentów miasta Poznania, Pielęgniarstwo Polskie. 2003:1(15): 273-76. 
10. Wołowski T., Kasperowicz A.: Wiedza uczniów szkół ponadgimnazjalnych na tematprofilaktyki AIDS. Hygeia Public Heath. 2012, 47(2): 227-230.

11. Pytka D, Krupienicz A.: Wiedza uczniów szkół średnich na temat HIV, AIDS. Badania porównawcze. Zdr Publ . 2006,116(4): 572-577.

najbardziej zagrożonych rejonów świata m.in. Afryki. Naukowcy próbują znaleźć 